\title{
Equitable Representation of Communities in Public Administration in Republic of Macedonia as One of the Copenhagen Political Criteria for EU Membership
}

\author{
Associate Prof. Abdula Azizi \\ SEE University - Tetovo, llindenska BB, 1200 \\ a.azizi@seeu.edu.mk \\ Doi:10.5901/ajis.2014.v3n3p66

\begin{abstract}
Given that the Republic of Macedonia is a candidate country for membership since 2005, with a tendency to join the European Union, in the framework of this paper will analyze the implementation of the Copenhagen political criteria. Through this paper I will address a political segment, which deals with the representation of the communities in Public Administration, because the topics in question usually promote various debates and policy assessments about the fulfillment of this criterion. The essence of this research has to do with an objective, outside political calculations, but is based on statistical analysis of institutions and official documents. Also, within the paper will analyze recent reports by the European Commission on the progress of Macedonia in the Euro- integration process, the part of the representation of the community. In this research, in addition to an analysis of official documents to represent the community, I made an analysis of interviews conducted with officials responsible for implementation of the Ohrid Framework Agreement, the charge for the fair representation of communities in central government bodies the Republic of Macedonia. Not only that, but I will draw lessons and conclusions which will have the aim to provide a motivating effect on the implementation of the Copenhagen political criteria.
\end{abstract}

Keywords: Copenhagen Political Criteria; Representation of the Communities; Republic of Macedonia; European Union.

\section{Introduction}

Copenhagen political criteria to represent one of the major tasks today, which candidate countries from the Western Balkans must meet them during the process of Euro-integration. Political criteria seems to be the most difficult for fulfillment, while taking into account the importance of inter-ethnic relations in Macedonia, in the framework of this paper is making an analysis that relates only to the representation of the communities in central organs. Scientific treatment of this topic, relating to political contradictions that exist among politicians, experts and ordinary citizens. For this reason, within the paper, are analyzed attitudes arising from the European Commission's progress report on Macedonia during the previous year; available legal instruments and institutions, which serve communities fair representation; The Ombudsman's report regarding the numerical representation in central institutions; then analysis of the interview with the political authority responsible for the fair representation of communities in Macedonia. Finally, conclusions have given to the question, which is the subject of study in this paper.

\section{Equitable Representation of Communities in Macedonia: Assessments Within the European Commission Progress Report 2013}

A European Commission report on the progress of Macedonia since 2013, among others, evaluates the fulfillment of the political criteria. This section examines the progress made by Macedonia towards meeting the Copenhagen political criteria, which require stability of institutions guaranteeing democracy, the rule of law, human rights and respect for and protection of minorities. It also covers regional cooperation, good neighborly relations with enlargement countries and Member States and compliance with international obligations, such as cooperation with the International Criminal Tribunal for the Former Yugoslavia.

The legal framework for public administration continues to be fragmented, affecting its unity, transparency and accountability. Despite several amendments, the scope of the main laws setting out the status, rights, duties and accountability of people employed by the state remained limited in terms of the number of institutions covered. Large numbers of public employees are therefore instead subject to specific legislation and/or general labour law and collective bargaining. Fragmentation hampers the collection of relevant data on public administration. Official figures on the total numbers of employees in the public sector, both permanent and temporary, are still not available, which makes it difficult to measure progress in achieving transparency and reform objectives. 
Policy improvements at both central and local level are still needed to combat politicization. All ongoing recruitment of public employees, irrespective of civil service status, needs to fully respect the principles of transparency and accountability and be based on merit. There are still cases of tailor-made vacancies and irregular recruitment of staff. Some recruitment has been carried out as a social policy measure, rather than as a response to institutional needs.

Targets of equitable representation, though largely achieved in the civil service, have not been met across the entire public sector. The recruitment procedure for members of non-majority communities still needs to be harmonized with general recruitment procedures. Efforts to meet equitable representation targets must be in balance with the real staffing needs of institutions. To address the above outstanding issues, the Macedonian authorities continued work on a new legislative framework that would replace the main laws on civil and public servants and enshrine the fundamental principles of transparency, merit and equitable representation. ${ }^{1}$

The main critiques for meeting the political criteria, are related to: the lack of political dialogue and compliance for strategic purposes in the state; setting off in the first place party interest above the interest of the state; slowed the process of decentralization; lack of transparency; practical exclusion of the merit system during employment in state bodies; deficiencies during the realization of the principle of fair representation in AP; Lack of independence in litigation; lack of media freedom etc.. Regarding public administration, the government continues to work towards the establishment of a new legal basis for the unification of the rules and the introduction of the principles of transparency and merit. Additional attempts should be made to ensure professionalism and independence in AP, and fair representation. ${ }^{2}$

\section{Legal and Institutional Basis for Equitable Representation of Communities in the Republic of Macedonia}

The principle of adequate and equitable representation is located in Section 4.2 Framework Agreement. This principle is incorporated in the Constitution of the Republic of Macedonia ${ }^{3}$, Article 8, paragraph 2, of the Constitution Amendment VI, which states: "appropriate and fair representation of citizens belonging to all communities in the state bodies and other public institutions at all levels."

This principle aims to realize the participation of members of all communities in all areas of the public sphere, in all organs of state, public service, public enterprises and local government.

Application of the principle, initiated more changes in laws : the Law on Civil Servants, Law on Public Enterprises, the Law on Local Self-Government, the Law on Ombudsman, and so on. ${ }^{4}$

The Government of the Republic of Macedonia, in February 2003 , approved the Basis for preparation of the program for improvement of adequate and equitable representation of communities in public administration and public enterprises, while in 2007, the Secretariat for the implementation of the Ohrid Agreement, approved strategies for adequate and equitable representation of community members who are not in the majority in the Republic of Macedonia, where the proposed measures and activities that must be undertaken in order to improve the adequate and equitable representation of all communities in the Republic of Macedonia. According to mentioned strategy, information about progress in fulfilling the principle of fair and adequate representation is provided and developed by the Annual report for adequate and equitable representation in the public sector of the Republic of Macedonia.

In addition, in 2006 the Committee of Ministers was established to monitor and coordinate activities pertaining to the improvement of adequate and equitable representation of community members in the state administration bodies and public enterprises.

The ombudsman is a body for the protection of the principles of equality and fair representation. In Article 77 , paragraph 2 of the Constitution of the Republic of Macedonia states as follows: (2) The Ombudsman protects the constitutional and legal rights of citizens when violated by bodies of state administration and other bodies an organization with public powers. The Ombudsman will pay particular attention to the protection of the principles of non-discrimination and equal representation of communities in public bodies at all levels and in other areas of public life.

In addition, Article 2 of the Law on Amending the Law on Civil Servants ${ }^{5}$ defined the obligation of the state

\footnotetext{
1 Commission Staff Working Document The Republic Of Macedonia 2013 Progress Report, Accompanying the document Communication From The Commission To The European Parliament And The Council, Enlargement Strategy and Main Challenges 2013-2014 \{COM(2013) 700 final\}, Brussels, 16.10.2013 SWD(2013) 413 final, p.10

2 Preliminary analysis of the EC Report on the progress of the R. of Macedonia for 2013, European Policy Institute-Skopje, 2013, p. 6

${ }^{3}$ Official Gazette no. 91/2001

${ }^{4}$ Report on the state of implementation of all policies emanating from the Ohrid Framework Agreement, Government Of The Republic Of Macedonia, Secretariat for the implementation of the Ohrid Framework Agreement, Skopje , 2012, pp.16-17

${ }^{5}$ Official Gazette, 40/03
} 
administration bodies for approval of annual plans for adequate and equitable representation of communities. Annual plans represent the current situation in this area, plans for employment, further expertise and training, and assessment of fiscal implications. That, along with the constitutional principle of equal access to employment thanks to the professionalism and competence (Article 12 of the Law on Civil Servants), the employment of civil servants applies the principle of adequate and equitable representation of citizens.

\subsection{Table of equal and fair representation of communities in the Republic of Macedonia}

With the amendments of the Constitution of the Republic of Macedonia in 2001 and the Law on the Ombudsman in 2003, the Ombudsman has jurisdiction to monitor the degree of implementation of the principle of adequate and equitable representation. In this context, the Ombudsman regularly conducts researches regarding the implementation of the principle of adequate and equitable representation of communities in the state bodies, bodies and units of local selfgovernment and public facilities and services and prepares special reports on the implementation of this principle and $\mathrm{He}$ submits it to the Assembly of the Republic of Macedonia.

Regarding the integration which is delegated to the Ombudsman, the data in the table are taken from the Annual Report of the Ombudsman for 2012.

Table 1. Equal representation of communities in the Republic of Macedonia in 2012

\begin{tabular}{|l|c|c|c|c|c|c|c|c|c|}
\hline Comparative Data & Totally & Macedonian & Albanian & Turkish & Roma & Serbian & Vlach & Bosnian & Others \\
\hline Managerial Position & 9901 & 7835 & 1464 & 151 & 20 & 181 & 93 & 54 & 102 \\
\hline Non-managerial position & 97950 & 73260 & 17687 & 2012 & 1363 & 1528 & 648 & 531 & 921 \\
\hline Employed & 107851 & 81095 & 19151 & 2164 & 1383 & 1709 & 741 & 585 & 1023 \\
\hline Percentage & 100 & 75.2 & 17.8 & 2 & 1.3 & 1.6 & 0.7 & 0.5 & 0.9 \\
\hline
\end{tabular}

Source: Annual Report of the Ombudsman for 2012, March 2013, p.38

Unlike last year, this year, the number of community members employed in central PA was increased to $2.3 \%$, while at the local level to $4.4 \%$. Despite this positive trend, a large number of institutions had not reached the appropriate level of representation of communities, especially in punitive institutions, courts, prosecutors, public enterprises, health funds, independent state bodies.

Table 2. Comparative data regarding the representation of the communities in PA

\begin{tabular}{|c|c|c|c|c|c|c|c|c|c|}
\hline Year & Empl. & Macedonian & Albanian & Turkish & Roma & Serbs & Vlach & Bosnian & Others \\
\hline 2012 & 107851 & $81095(75.2)$ & $19151(17.8)$ & $2164(2)$ & $1383(1.3)$ & $1709(1.6)$ & $741(0.7)$ & $585(0.5)$ & $1023(0.9)$ \\
\hline 2011 & 102103 & $77897(76.3)$ & $17598(17.2)$ & $1691(1.7)$ & $1304(1.3)$ & $1665(1.6)$ & $678(0.7)$ & $387(0.4)$ & $901(0.9)$ \\
\hline 2010 & 82555 & $63761(77.2)$ & $13966(16.9)$ & $1340(1.6)$ & $574(0.7)$ & $1315(1.6)$ & $570(0.7)$ & $256(0.3)$ & $773(0.9)$ \\
\hline 2009 & 69148 & $55266(79.9)$ & $9712(14)$ & $895(1.3)$ & $551(0.8)$ & $1301(1.9)$ & $524(0.8)$ & $259(0.4)$ & $640(0.9)$ \\
\hline 2008 & 67728 & $55193(81.5)$ & $8642(12.7)$ & $825(1.2)$ & $527(0.8)$ & $1269(1.9)$ & $449(0.7)$ & $205(0.3)$ & $618(0.9)$ \\
\hline 2007 & 59629 & $49923(83.7)$ & $6429(10.8)$ & $649(1.1)$ & $464(0.8)$ & $1050(1,8)$ & $405(0.7)$ & $201(0.3)$ & $508(0.8)$ \\
\hline
\end{tabular}

Comparative data from the table shown an increase in the number of employees in PA in general, while the principle of equitable representation of communities in central government bodies and local, public enterprises and service marks mild improvement, though some institutions do not apply this principle. Representation in managerial positions of nonmajority communities is still not in satisfactory level, particularly in the independent state bodies and public health authorities.

\subsection{Interview}

Extract from the Interview of Deputy Prime Minister of Macedonia, Musa Xhaferi. ${ }^{6}$

1. How do you assess the implementation of the Ohrid Framework Agreement after 12 years of its signing?

${ }^{6}$ Radio Free Europe, January 7, 2013 
Changes are made, as in the Constitution as well as in many laws, while supposed to exceed a time to view their practical realization. I think these normative changes have contributed to the stability of the country, while also remaining open topics which in the future will have to be resolved.

2. During these 12 years progressed, why you have not analyzed the effects and shortcomings, how to act further?

Within institutions, there is qualitative analysis, probably not debated publicly, and there are different perceptions on this issue. Sometimes there is the political misuse of this topic.

3. When it comes to employment and fair representation of the communities, according to government competitions, many community members that have received decisions for work, now they are staying at home and receive salaries? How would you comment this?

I am not saying that there is no obstacle, but the perception that they stay at home is erroneous, since there also are those who are not yet systematized workplace, due to procedures, which must pass each to place in appropriate institutions.

In this process, representatives of the communities are employed to achieve the right balance in representation. Thus, not only are employed Albanians and other communities, but also Macedonian. In this race, if we would have employed continuously Macedonians, then the goal will not be achieved.

The aforementioned estimates should be understood more as a political assessment of the perspective of representatives in power, while the reality of this problem may be different. Particularly, there is a truth which everyone knows, but that silence during the selection of candidates for employment associated with fair representation, and that is the issue that their selection is made only by belonging to the subject who is in power, not according to the quality and the professionalism of the candidates presented in competition. The key for employment continues to be an exclusively partisan affiliation of parties in power, while bypassing all other measurable criteria.

What irritates ordinary people? It is the selection of candidates with lower performance and improper professional, against candidates with professional performance that are not part of the political parties in power. Such representation only quantitative, not only goes to the detriment of fair and adequate representation, but also seriously undermines the prospects of young people who specialize to work in AP.

On the other hand, fair representation requires a concrete strategy with other supporting instruments (Financial and institutional) to be achieved fair representation, but also a concrete time frame in which affirmative measures will be undertaken for fair representation of communities less represented. While extending these measures, should raise awareness for understanding, on the part of overrepresented.

\section{Conclusions}

- The implementation of the principle of adequate and equitable representation requires taking continuous actions

- There is some progress in implementing the principle of equitable representation. In a number of institutions, the percentage does not reflect the composition of the population

- The unequal application of the principle of adequate and equitable representation in non-managing and managing staff is striking. Members of smaller communities are represented satisfactorily as non-managing staff. The management staff is composed only of members of the Macedonian and Albanian ethnic community, while members of smaller ethnic communities are not represented in the managing staff

- Implementation of the principle of adequate and equitable representation of all communities, especially among funds, public companies, educational-corrective institutions, appellate courts, senior public prosecutors, and in the application of this principle in setting, managing staff in the state administration bodies, for which constant upgrading of the system for implementation of this constitutional principle is required

My general conclusion is that this year the state bodies showed progress in implementing the principle of adequate and equitable representation, whereas in some institutions a progress was made, while in others there is no change in the situation compared to previous years.

\section{References}

Annual Report of the Ombudsman for 2012, Skopje, March 2013

European Council in Copenhagen 21-22 June 1993, Conclusions of the Presidency, SN 180/93.

Interview of Deputy Prime Minister of Macedonia, Musa Xhaferi, Radio Free Europe, January 7, 2013 
Law on Civil Servants, adopted in July 2000 and published in the "Official Gazette of the Republic of Macedonia" No. 59/2000

Preliminary analysis of the EC Report on the progress of the R. of Macedonia for 2013, European Policy Institute-Skopje, 2013, p.6

Report on the state of implementation of all policies emanating from the Ohrid Framework Agreement, GOVERNMENT OF THE Republic of Macedonia, Secretariat for the implementation of the Ohrid Framework Agreement, Skopje, 2012

Staff Working Document The Republic Of Macedonia 2013 Progress Report, Accompanying the document Communication From The Commission To The European Parliament And The Council, Enlargement Strategy and Main Challenges 2013-2014 \{COM(2013) 700 final\}, Brussels, 16.10.2013 SWD(2013) 413 final, p.10 